\title{
The Habitat and Description of a New Genus of Sulphur Bacterium
}

\author{
By J. B. LACKEY AND ELSIE W. LACKEY \\ Department of Civil Engineering, The University of Florida, \\ Gainesville, Florida, U.S.A.
}

(Received 19 December 1960)

\begin{abstract}
SUMMARY
A new species and genus of colourless sulphur bacteria, for which the name Thiodendron mucosum is proposed, is described from two habitats in Florida. Its morphology and physiology relate it to the Beggiatoaceae, but it is branching, nonfilamentous and non-motile so it should not be included in that family and a new family should be created for it. Some characteristics of its environment are discussed and also the organisms common to such an environment. It is probable that the particular organisms are closely connected to the metabolism of sulphur, while their variety and biomass attribute an important role to sulphur in nature, especially in environments containing little or no oxygen.
\end{abstract}

\section{INTRODUCTION}

In January 1956 a collection of sulphur bacteria was made at Warm Mineral Spring near Venice in south-west Florida, U.S.A. One of these was considered to be new. Dr E. G. Pringsheim of the Botanische Austatem, The University of Göttingen, Germany, was visiting the laboratory at the time and he concurred in this view. Since that date the organism has been studied intensively, and has been found at only one other location, despite diligent search.

\section{METHODS}

The work reported here consisted of making field collections from sulphur springs and other environments, and studying the organisms in the laboratory under high magnifications. Physicochemical characteristics of the waters were also determined where possible, and some staining was done. The organisms stained very unevenly by Gram's method, overstained intensely with carbol-fuchsin and did not take up methylene blue. Apparently the large amount of jelly-like material interferes greatly with the stains used. Many laboratory culture methods were tried, but since none has been successful thus far, they are not described here.

The State of Florida, U.S.A., has seventeen first-magnitude springs (Ferguson, Lingham, Love \& Vernon, 1947), as well as vast numbers of smaller ones. Many of these are sulphur springs, giving off $\mathrm{H}_{2} \mathrm{~S}$ and supporting white growths of sulphur bacteria, principally Beggiatoa and Thiothrix. These growths appear as a white coating on the spring bottom and sides and often extend far down the run. All the springs are constant in their characteristics, although differing sharply among themselves; for this reason Odum (1957) referred to them as excellent laboratories. Most 
of the sulphur springs show a single dominant species of sulphur bacteria with others in smaller numbers. The white coating is due to the dominant organism. Table 1 lists the sulphur-accumulating bacteria belonging to the families Beggiatoaceae and Thiobacteriaceae which were abundant at some of the eleven stations studied.

Warm Mineral Spring is an exception to the single dominant condition because its huge population consists principally of six species of Beggiatoa and five species of Thiothrix and because dominance shifts. It is also the only spring whose salt content is so high; Table 2 gives its physicochemical characteristics. Its temperature gradient suggests that the water comes from Ocala limestone at a depth of about $800 \mathrm{ft}$., and Dr A. P. Brooks (private communication) suggested that the water is $\mathbf{5 0} \%$ connate sea water and $\mathbf{5 0} \%$ fresh water. There is virtually no fluctuation in any characteristic, except that of light, and this only to a depth of about $65 \mathrm{ft}$. The water is very clear in the early morning, but after sunrise it becomes cloudy because of a photochemical precipitation of sulphur. Sulphur granules are easily found free in the sand and water; this photochemical mechanism was not mentioned by Ivanov (1957) in addition to his account of the precipitation of sulphur by bacteria, although indeed he was working principally with sulphur in underground formations.

\section{Table 1. Occurrence of colourless sulphur-accumulating bacteria at eleven locations}

All these bacteria were identified during the years $1956-60$ by direct microscopic examination, except Thiobacillus denitrificans which was cultured. The identification of Thiobacterium bovista might be questionable.

\section{Locations}

1. Warm Mineral Spring, Fla. Half salt.

7. Sanibel Island, Fla. Fresh.

2. Orange Springs, Fla. Fresh.

8. Hampton Springs, Fla. Fresh.

3. Welaka Mud Springs, Fla. Fresh.

4. Sarasota, Fla., Ringling Fountain. Fresh.

5. Green Cove Springs, Fla. Fresh.

9. Lake Alice, Gainesville, Fla. Fresh.

6. Fort Myers, Fla. Fresh.

10. Titusville, Fla., Inland Waterway. Salt.

11. Woods Hole, Mass., Salt Marshes.

\begin{tabular}{|c|c|c|c|c|c|c|c|c|c|c|c|}
\hline & \multicolumn{11}{|c|}{ Location } \\
\hline & 1 & 2 & $\mathbf{3}$ & 4 & 5 & 6 & 7 & 8 & 9 & 10 & 11 \\
\hline Achromatium oxaliferum & $\mathbf{X}$ & . & . & . & . & . & . & . & $\mathbf{x}$ & . & $\mathbf{X}$ \\
\hline A. volutans & $\mathbf{x}$ & . & . & . & . & . & . & . & . & $\mathbf{X}$ & $\mathbf{x}$ \\
\hline Beggiatoa alba & $\mathrm{x}$ & $\mathrm{x}$ & $\mathbf{x}$ & $\mathbf{x}$ & $\mathbf{x}$ & . & $\mathbf{x}$ & $\mathbf{x}$ & $\mathbf{x}$ & $\mathbf{x}$ & $\mathbf{x}$ \\
\hline B. arachnoidea & $\mathbf{X}$ & . & $\mathbf{X}$ & . & $\mathbf{x}$ & . & $\cdot$ & . & $\mathbf{x}$ & $\mathbf{x}$ & $\mathbf{X}$ \\
\hline B. gigantea & $\mathrm{x}$ & . & . & . & $\cdot$ & . & . & . & - & $\mathbf{x}$ & $\mathbf{X}$ \\
\hline B. leptomitiformis & $\mathbf{x}$ & . & $\mathbf{x}$ & . & $\mathbf{x}$ & . & $\mathbf{x}$ & $\mathbf{x}$ & $\mathbf{x}$ & - & $\mathbf{x}$ \\
\hline B. minima & $\mathbf{X}$ & . & . & . & . & . & . & . & $\mathbf{x}$ & . & $\mathbf{x}$ \\
\hline B. mirabilis & $\mathbf{X}$ & . & . & . & . & - & . & . & · & $\mathbf{X}$ & $\mathbf{X}$ \\
\hline Thiodendron mucosum n.sp. & $\mathbf{x}$ & . & . & . & . & . & - & - & . & $\mathbf{X}$ & . \\
\hline Thiospirillopsis floridana & $\mathbf{x}$ & . & . & . & . & . & . & . & . & . & . \\
\hline Thiothrix annulata & . & . & . & . & . & . & . & . & $\mathbf{x}$ & . & $\mathbf{x}$ \\
\hline T. marina & $\mathbf{x}$ & . & . & . & . & . & . & . & . & $\mathbf{X}$ & $\mathbf{x}$ \\
\hline T. nivea & $\mathbf{x}$ & . & $\mathbf{x}$ & . & $\mathbf{X}$ & $\mathbf{x}$ & $\mathbf{x}$ & $\mathbf{x}$ & $\mathbf{x}$ & . & $\mathbf{x}$ \\
\hline$T \cdot$ tenuis & $\mathbf{x}$ & . & $\mathbf{x}$ & $\mathbf{x}$ & $\mathbf{x}$ & - & . & $\mathbf{x}$ & $\mathbf{X}$ & - & $\therefore$ \\
\hline T. tenuissima & . & . & . & . & . & - & . & . & $\mathbf{x}$ & - & $\mathbf{x}$ \\
\hline Macromonas bipunctata & $\mathbf{x}$ & - & - & . & - & - & . & . & . & $\mathbf{X}$ & $\mathbf{x}$ \\
\hline M. mobilis & . & . & . & . & - & - & - & . & $\mathbf{X}$ & . & $\mathbf{x}$ \\
\hline Thiobacillus dentrificans & $\mathbf{x}$ & $\mathbf{x}$ & $\mathbf{x}$ & - & - & - & - & $\mathbf{x}$ & $\mathbf{x}$ & - & $\mathbf{x}$ \\
\hline Thiobacterium bovista? & $\mathbf{X}$ & . & . & - & - & - & - & - & $\cdot$ & - & $\mathbf{x}$ \\
\hline Thiospira winogradskyi & $\mathbf{x}$ & - & . & . & . & - & - & . & . & $\mathbf{X}$ & $\mathbf{x}$ \\
\hline T. bipunctata & $\mathbf{x}$ & . & . & - & . & . & - & . & $\mathbf{x}$ & $\mathbf{x}$ & $\mathbf{x}$ \\
\hline Thiovulum majus & $\mathbf{x}$ & - & - & - & - & $\mathbf{X}$ & - & $\mathbf{x}$ & $\mathbf{x}$ & $\mathbf{x}$ & $\mathbf{x}$ \\
\hline & & & pr & & & & & & & & \\
\hline
\end{tabular}


Table 2. Physicochemical characteristics of Warm Mineral Spring

\begin{tabular}{|c|c|c|}
\hline & Ferguson et al. (1947) & Morgan (1956) \\
\hline Dissolved solids & 17,812 p.p.m. & 17,988 p.p.m. \\
\hline Iron & 0.12 p.p.m. & 0.09 p.p.m. \\
\hline Calcium & 766 p.p.m. & 596 p.p.m. \\
\hline Magnesium & 471 p.p.m. & 567 p.p.m. \\
\hline Silica $\left(\mathrm{SiO}_{2}\right)$ & 18.00 p.p.m. & 23.80 p.p.m. \\
\hline Sodium, potassium & 5,124 p.p.m. & . \\
\hline Chloride & 9,350 p.p.m. & . \\
\hline Bicarbonate $\left(\mathrm{HCO}_{3}\right)$ & . & 167 p.p.m. \\
\hline Total hardness $\left(\mathrm{CaCO}_{3}\right)$ & 3,846 p.p.m. & 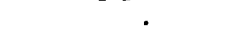 \\
\hline Temperature & . & $84^{\circ}$ F. $\pm 2^{\circ}$ \\
\hline pH value & - & $7 \cdot 2 \pm 0 \cdot \overline{2}$ \\
\hline Volatile solids $\left(600^{\circ}\right.$ for $\left.30 \mathrm{~min}.\right)$ & . & $17 \cdot \overline{1} \%$ \\
\hline Nitrate & - & 0.05 p.p.m. \\
\hline Dissolved $\mathrm{PO}_{4}$ & - & 0.0016 p.p.m. \\
\hline Total $\mathrm{PO}_{4}$ & - & 0.0037 p.p.m. \\
\hline C.O.D. (dichromate) & . & 813 p.p.m. \\
\hline Dissolved oxygen* & . & 0.0 p.p.m. \\
\hline $\mathrm{H}_{2} \mathrm{~S}$ & - & 0.162 p.p.m. \\
\hline HS & . & 0.078 p.p.m. \\
\hline $\mathrm{SO}_{4}$ & . & 1704 p.p.m. \\
\hline
\end{tabular}

* Odum says that interference accounts for this value; if the interference is removed, a value of $1 \cdot 0$ is obtained.

\section{RESULTS}

Occurrence of the new bacterium

The first specimens of the new organism were found in January 1956. Collections of the dense growths of sulphur bacteria were brought to the laboratory for studies of the widths of the various types. Among these were arboroid colonies densely packed with what appeared to be sulphur granules. Most of these were attached to the blue-green alga Lyngbya. Some of the colonies had a spread of over $2 \mathrm{~mm}$. They were examined alive, with a Zeiss Optovar microscope at magnifications of 100-1600 diameters. Some were set aside in small moist chambers (Petri dishes containing filter paper saturated with salt water) for subsequent examination. It was concluded that the new organisms represented a free-living sulphur bacterium of a new type. A second trip to the spring 3 weeks later yielded no specimens, but it has since been found many times in this spring, and as far as half a mile down the run. Many other sulphur springs in Florida have been investigated without finding the new organism nor was it found in $\mathrm{H}_{2} \mathrm{~S}$-containing water at La Jolla, California, at Woods Hole, Massachusetts, in the desert around Las Vegas, Nevada, and in aquaria containing good natural growths of Beggiatoaceae in the Narragansett Marine Laboratory, Rhode Island. However, in February 1959 a heavy coating of sulphur bacteria was found in shallow water along the intracoastal waterway at Titusville, Florida. Examination revealed many colonies of the new bacterium, and it has been found at all subsequent visits to this location. These sulphur bacteria (Beggiatoales) were in a grossly polluted situation behind a crab-meat packing plant. There should be no pollution at all in Warm Mineral Spring (now being exploited as a spa), but it should be noted that the volatile solids are very high for such a situation. 


\section{Description of the organism}

This description is based primarily upon microscopic examination of unkilled, unfixed material. Two small blobs of viscous grease were put on a slide, a drop of water containing the organism was added between the bits of grease, and a no. 1 thickness cover glass was added. This permitted brightfield and darkfield examination at magnifications up to 1600 diameters.

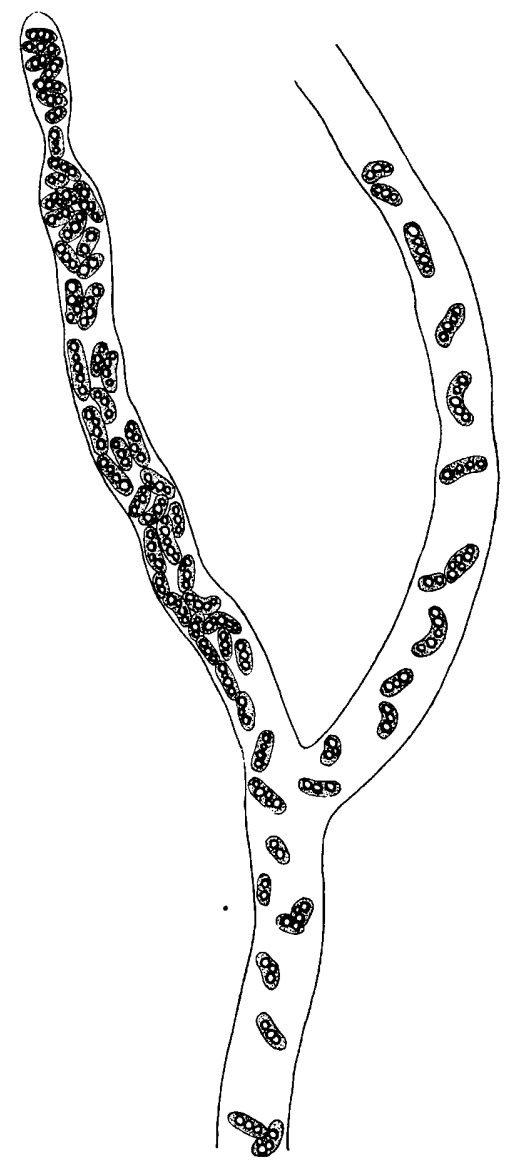

Fig. 1. Drawing of a portion of a living colony of Thiodendron mucosum to show distribution of sulphur and cells within the mucus. $\times 1600$.

The organism, which will be referred to as Thiodendron, consists of rod-shaped bacteria 3-9 $\mu$ long and $1 \cdot 0-2 \cdot 5 \mu$ in diameter, forming dendroid colonies up to $3000 \mu$ across, in a jelly-like matrix (Pl. 1, figs. 1, 2, 4; Fig. 3). In this jelly, the individual organisms are distributed at random, but tend to be most numerous near the ends of the colony. Most of the organisms are of similar size (3-5 $\mu$ long $\times 1.5 \mu$ diameter), but often the organisms at the swollen ends of the branches are three times this size (Fig. 3). These large forms appear to be typical of older colonies, because quite young colonies, although they may have swollen tips, normally 
exhibit only smaller forms. The smaller forms usually have 3 to 8 sulphur granules which vary in size, but which are generally arranged along the linear axis. The organisms in the larger tips may have as many as 20 sulphur granules which vary in size, but which are generally arranged along the linear axis, rather crowded, and when a tip is crowded with organisms it is much darker than the distal part of the colony (Fig. 3).

Evidence that the granules are indeed sulphur is based upon the type of the inclusion, round bodies with uniform black edges (the 'droplets' of Winogradsky), and upon the recovery of sulphur on evaporating extracts of the colonies with carbon disulphide. The colony does not show branching until it is at least several cell-lengths long. While there is no definite pattern for the arrangement of the bacteria within the common jelly, most of the bacteria have their long axis parallel to the filament axis.

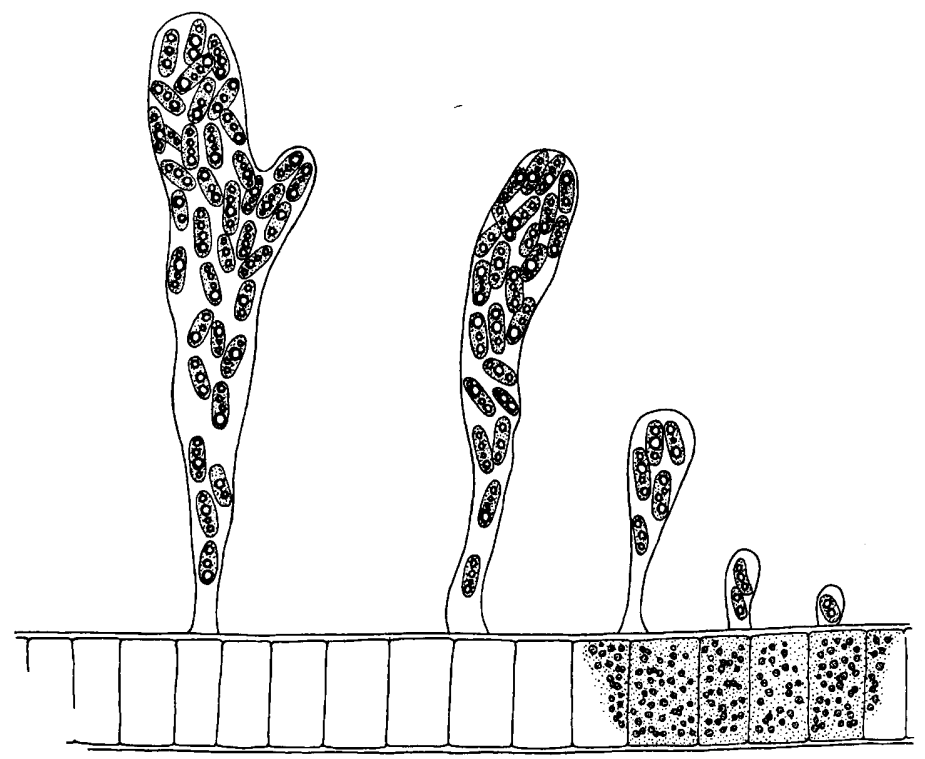

Fig. 2. Drawing of five young living colonies of Thiodendron mucosum attached to a filament of Lyngbya. $\times 1600$.

Outlines of the bacterial forms are very difficult to see. In fact, their shape was first suggested by the linear clumps of sulphur granules (Fig. 1). Their internal make-up is quite homogeneous, with very nearly the same optical density as the jelly. One gets the impression of branching jelly crowded with sulphur granules. However, the bases of the mucous fingers are frequently almost devoid of bacteria. Also, when colonies are left under a cover glass in a moist chamber, after $24 \mathrm{hr}$. they begin to lose their sulphur, and pale ghosts of the bacteria become visible. Sometimes bacterial forms showing a constriction may be seen, as if they were undergoing binary fission. The bacterial forms stain very poorly, if at all, by Gram's method. Acids cause swelling and disintegration of the mucilage, and distort it. The bacterial forms are not coloured by iodine. 
Older colonies are quite arboroid in habit (Pl. 1, figs. 1, 2, 4). Superficially they resemble Zooglea ramigera. A given colony tends toward uniformity in the size of its club-shaped parts (Fig. 3). Colonies over $2 \mathrm{~mm}$. across have been found on many occasions. No holdfasts have ever been detected, but the attachment is strong. A colony brushed by a rotifer or ciliate bends, but is not detached. Usually attachment is to a filament of Lyngbya (Fig. 2), but occasionally it is to some other surface. Plate 1, fig. 2, shows a colony attached to the stalk of a colonial vorticellid. Colonies

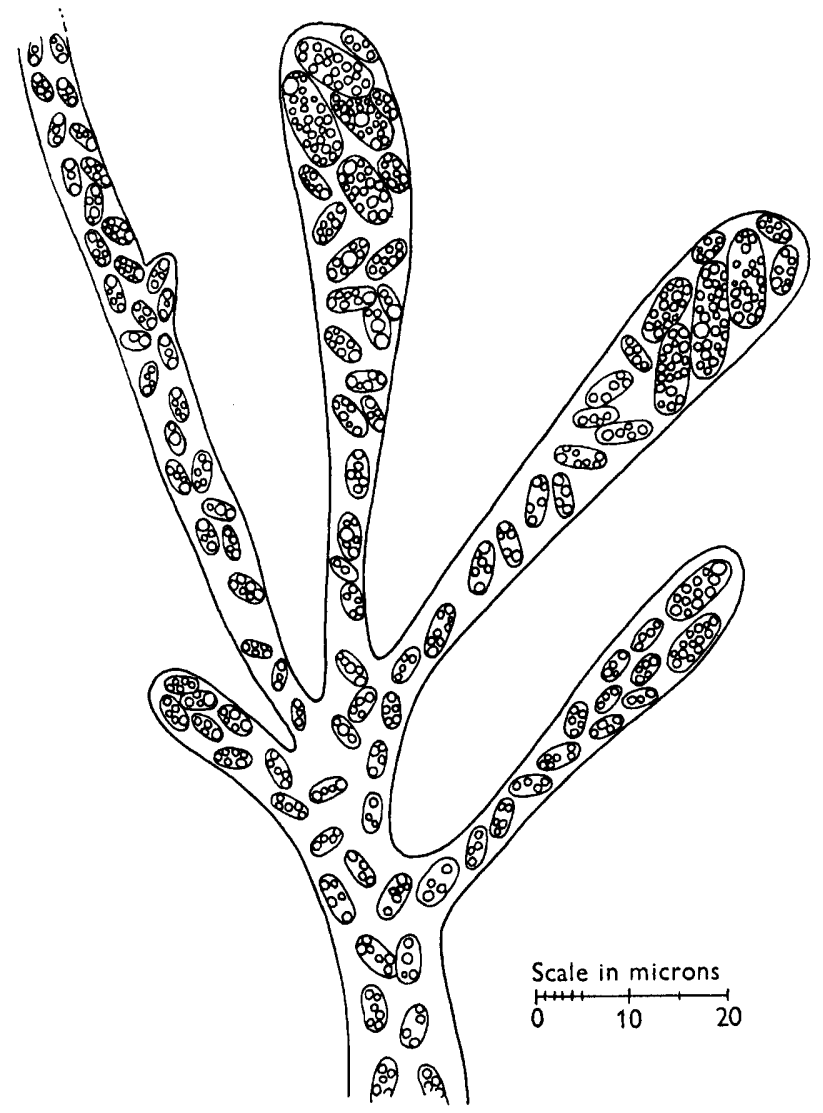

Fig. 3. Portion of a mature living colony of Thiodendron mucosum to show the larger bacterial forms near the swollen ends of branches. $\times 1600$.

evidently start from a single motile organism which settles down and grows out. Colonies with as few as three bacterial forms (Fig. 2) may be seen, already becoming club-shaped. Bacterial forms leaving the jelly of a colony have not been seen.

The organism has not been successfully cultivated in the laboratory. Colonies remain intact, but with no growth for several days, in a moist chamber. During this time, the sulphur granules gradually disappear. The temperature of Warm Mineral Spring is a uniform $84^{\circ} \mathrm{F} .\left(29^{\circ} \mathrm{C}\right.$. $)$, and that of the intracoastal waterway at a time when the organism was taken there was $55^{\circ} \mathrm{F} .\left(13^{\circ} \mathrm{C}\right.$. $)$.

Colonies have been kept apparently thriving for 3 months at $72^{\circ} \mathrm{F}$. $\left(20^{\circ} \mathrm{C}\right.$.) in 
jars of Warm Mineral Spring water, but colonies picked out and transferred to various liquid culture media invariably died within a few days. No increase in visible sulphur content, nor in viability resulted when such colonies were exposed to $\mathbf{0} \cdot \mathbf{3}-\mathbf{3 \cdot 0} \%$ of hydrogen sulphide. This species did not show an ability to oxidize hydrogen sulphide under the conditions in the laboratory, being different from Sphaerotilus in this respect, as reported by Skerman, Dementjeva \& Carey (1957), and by Waitz \& Lackey (1959). Scotten (1951) also reported that Beggiatoa did well when small amounts of hydrogen sulphide were present. More recently Faust \& Wolfe (1961) secured pure cultures of Beggiatoa without adding hydrogen sulphide, and we normally obtain massive cultures of Beggiatoa with other organisms in the same manner. However, every time the organism Thiodendron has been taken, enough $\mathrm{H}_{2} \mathrm{~S}$ was present in its environment to be detectable by its odour. Hydrogen sulphide is present constantly in the Warm Mineral Spring. Sulphide determinations show amounts varying around $0 \cdot 1$ p.p.m.; calculations show $\mathrm{H}_{2} \mathrm{~S}$ at about $0 \cdot 16$ p.p.m., and HS about 0.08 p.p.m. These are manifestly considerably below limiting factors for many organisms, certainly for Thiodendron.

The organism Thiodendron is another addition to the long list of parallel forms found in the lower plants. The organism essentially is a collection of rod-shaped bacterial forms in a common jelly, apparently not organically connected to each other. The same is true of Zooglea ramigera, whose cells are smaller and without sulphur. Even the dendroid habits of the two organisms are similar. Except for the branching of the jelly, almost the same comparison could be made with the bluegreen algae Aphanothece and Bacillosiphon. Pringsheim (1949) discussed possible relationships between bacteria and Myxophyceae, and this new organism adds material for that discussion.

\section{Taxonomic position of Thiodendron}

The organism occurs in sufficient abundance and is sufficiently distinctive to represent a valid species. Its resemblance to Zooglea is superficial, and the latter never accumulates sulphur, although a number of experiments has been made in attempts to induce this. The new organism does not accumulate iron in its sheath and does not resemble other jelly-inhabiting bacteria such as Nevskia or Leuconostoc. Devidé (1952) described as new colourless sulphur-accumulating bacteria, Thioglea, which live within jelly, but these are non-branching, oval or elongate masses. They would seem to be the closest relatives of Thiodendron even to the detail that cell outlines are difficult to make out. However, Devide' thinks they might belong to the Achromatiaceae, which Thiodendron obviously does not.

The accumulation of sulphur granules within the cell is the most striking characteristic of Thiodendron. This is true of Beggiatoa, Thiothrix, Thioploca and Thiospirillopsis. Thiothrix is attached; the others move about freely. The cells of each of these (if colonial; Thiospirillopsis is not) are in organic apposition, whereas Thiodendron cells may be far removed from each other, in older colonies. The family Beggiatoaceae, then, shows considerable variation among its respective genera, and this new genus is certainly a related one. In Achromatium there are free sulphur granules, but also large calcium carbonate inclusions and the cells are without jelly and freely motile. It does not seem that Thiodendron is closely related to this genus. Neither does it seem related to the families Vitreoscillaceae and Leucotrichaceae. 
The only other possible relative seems to be Thiobacterium bovista of the family Thiobacteriaceae. This species is rod-shaped, about the same size and is described as having one to four sulphur granules within each cell. Furthermore it is colonial, but the colonies are bladder-like. Thiodendron in some respects is quite similar. But it has few similarities to Thiospira or Thiobacillus, the other members of the family Thiobacteriaceae.

Thiodendron never shows colour and cannot be mistaken for a blue-green alga or any of the Thiorhodaceae. It is therefore considered a new genus and species for which the name Thiodendron mucosum is proposed. This is from the Greek nouns thion, sulphur, and dendron, tree (a sulphur tree) and the Latin adjective mucosus, slimy. Thiodendron is neuter. Pringsheim, when he saw the organism, suggested Thiobrachys for it, but this proved to be etymologically unacceptable. The taxonomic position of many of the sulphur bacteria seems a matter of diverse opinion, as shown by Bisset \& Grace (1954). This one seems completely unrelated morphologically to many Beggiatoales and to the Achromatiaceae; in addition, no movement of the bacterial forms within the jelly, or of the colony as a whole, has been observed. Its lack of colour is enough to exclude it from the Thiorhodaceae or the Athiorhodaceae, even though its sulphur relationships are still not understood. It seems preferable to place it in the order Beggiatoales despite its apparent lack of motility in vegetative cells. However, a new family, Thiodendraceae, is proposed and it is hoped that the organism may become better known.

\section{Habitat and associations}

The occurrence of a unique organism in a unique environment usually brings the question 'What factors are responsible for its presence?' It was at first thought that the half sea-water concentration, $\mathrm{H}_{2} \mathrm{~S}$ without pollution, and the temperature in Warm Mineral Spring were responsible for the occurrence of Thiodendron, but then it was found at Titusville. No analysis of the water there is available, but its salinity was found to be about 17,000 p.p.m. The water temperature at the time of collection was $55^{\circ} \mathrm{F} .\left(12.5^{\circ} \mathrm{C}\right.$.) and there were ample visual evidences of organic pollution. In June 1959 Pagosa Hot Spring in Colorado was examined; this spring is hot to warm, and has a high salt content. Beggiatoa and Thiothrix species occurred there, but no Thiodendron in the samples taken. At present physicochemical factors do not explain its occurrence.

However, Warm Mineral Spring has a unique flora and fauna; it seems ideal for sulphur bacteria. All species of Beggiatoa are abundant; $\boldsymbol{B}$. gigantea, which has not been recorded from fresh water and which we have not found elsewhere in dense aggregates, may be scooped up there in great handfuls. Symploca has not been found, but many other groups are (see Table 3). Thiospirillopsis floridanus, described by Uphof (1927) from Welaka, Florida, 200 miles north, has been found once in some thirty trips to Warm Mineral Spring. It is thus recorded now (the second record?) from brackish as well as fresh water.

In Warm Mineral Springs the blue-green algae are unusual, so are the diatoms, green algae and flagellates; few filamentous green algae occur and only an occasional green euglenid has been taken. The dominant green flagellate is Trentonia flagellata, which apparently had not been seen until the present work since it was described by Stokes (1886); Hollande (1952) called it a synonym of Vacuolaria, but the original 
description is valid. Incidentally, it was also a dominant near the bottom of Green Hill Pond, a Rhode Island salt pond of low salinity, in July 1960. The rhizopods are few, but include two Foraminifera. The ciliata are mostly salt-water types, and include several undescribed species. Little work has been done with other organisms, but some flatworms are new and a new nereid was described by Hartman (1959), while two of the three microcrustacea are species which Dr H. C. Yeatman (personal communication, 1959) believes to be distinct undescribed species. Many other groups are represented by few species, or are absent. The whole picture is of a very unusual environment, which has produced unusual organisms.

Table 3. The number of genera or species of various organism groups found at Warm Mineral Spring

About $5 \%$ have not been identified and there are some which are new. All identifications were made upon living organisms by direct microscopic examination

$\begin{array}{lrlr}\text { Sulphur bacteria } & 34 & \text { Dinoflagellata } & 6 \\ \text { Blue-green algae } & 27 & \text { Bacillarieae (Diatoms) } & 20 \\ \text { Green algae and Charales } & 6 & \text { Zooflagellata } & 24 \\ \text { Euglenida } & 24 & \text { Rhizopoda } & 26 \\ \text { Chloromonadida } & 1 & \text { Ciliata } & 99 \\ \text { Cryptomonadida } & 3 & \text { Metazoa } & 32\end{array}$

\section{DISCUSSION}

It seems reasonable to suppose that an organism is a product of its environment; on this score a highly specialized environment such as Warm Mineral Spring might reasonably be supposed to have the very special or rare organisms such as Thiodendron appears to be. Factors common to Titusville and Warm Mineral Spring appear to include degree of salinity, presence of $\mathrm{H}_{2} \mathrm{~S}$ and some few related characteristics. But the environment at Titusville is not constant, so there the comparison ends. Thiodendron is such a striking organism that were it not greatly restricted in occurrence it would have been reported long before this.

In this case, the particular organisms present in abundance, and constantly, emphasize the importance of sulphur, especially hydrogen sulphide, in the energy relationships of a given locale. These energy relationships may be expressed by the formula: $\mathrm{H}_{2} \mathrm{~S} \rightarrow \mathrm{S}+2 \mathrm{H}+2 e$. The free energy liberated by this reaction is $-7 \cdot 89 \mathrm{Cal}$. Lamanna \& Malette (1953) state that the Beggiatoaceae use as an energy source the oxidation of $\mathrm{H}_{2} \mathrm{~S}$. Since $\mathrm{H}_{2} \mathrm{~S}$ oxidizes readily in the presence of minute quantities of metals, Warm Minerals Spring with a flow of about 9,000,000 gallons daily, and an $\mathrm{H}_{2} \mathrm{~S}$ content of $0.162 \mathrm{mg}$. $/ \mathrm{l}$. provides a large source of energy to those microorganisms able to obtain it. Some of the organisms found in Warm Mineral Spring are ubiquitous; others are characteristic of an environment containing $\mathrm{H}_{2} \mathrm{~S}$. When a jar containing a large variety of Warm Mineral Spring organisms is tightly closed, most of the organisms die within $24 \mathrm{hr}$. Table 4 gives a list of the resistant organisms.

There are many organisms which use soluble sulphur directly in their metabolism. But there are also many which ingest either the free sulphur granules, or sulphur bacteria. With some ciliates, ingested bacteria may be clearly observed in food vacuoles. Frontonia ingests some of the smaller Beggiatoales; others ingest Thiovulum, Chromatium or Macromonas bipunctata. This ingestion suggests a mechanism for the transfer of $\mathrm{S}$ from $\mathrm{H}_{2} \mathrm{~S}$ to the soil as elementary sulphur. Beggiatoa (and 
similar bacteria, perhaps including Thiodendron) oxidize $\mathrm{H}_{2} \mathrm{~S}$ to $\mathrm{S}$ : this may be oxidized in turn to $\mathrm{H}_{2} \mathrm{SO}_{4}$, but in an alkaline medium (the sea, Warm Mineral Spring) the acid is neutralized. When the bacteria are ingested, there may be a direct deposition of their contained elementary $S$ in the soil. Indeed, free $S$ is readily found in bottom deposits at Warm Mineral Spring. The water there contains adequate carbonates, and at least 0.05 p.p.m. $\mathrm{NO}_{3}$, also $\mathrm{CO}_{2}$, so that respiration is no problem, yet dissolved oxygen remains low. There is a high organic content in Warm Mineral Spring water which evidently serves as food for the micro-organisms. Considerable quantities of Chara and four genera of blue-green algae, Chroococcus, Gomphosphaeria,

Table 4. Organisms alive after $48 \mathrm{hr}$. saturation of Warm Mineral Spring water with hydrogen sulphide

All identifications based upon direct microscopic examination.

\author{
1. Beggiatoa alba \\ 2. B. arachnoidea \\ 3. B. gigantea \\ 4. B. leptomitiformis \\ 5. B. minima \\ 6. B. mirabilis \\ 7. Chromatium spp. \\ 8. Chroococcus turgidus \\ 9. Gomphosphaeria aponina \\ 10. Lyngbya sp. \\ 11. Oscillatoria spp. \\ 12. Spirulina major \\ 13. S. princeps \\ 14. Amphiprora sp. \\ 15. Amphora ovalis \\ 16. Biddulphia sp.
}

\author{
17. Navicula spp. \\ 18. Petalomonas sp. \\ 19. Gymnodinium sp. \\ 20. Cyathomonas truncata \\ 21. Bicoeca lacustris \\ 22. Bodo reniformis \\ 23. Monas vulgaris \\ 24. Spirochaeta spp. \\ 25. Amoeba sp. \\ 26. Cryptopharynx sp. \\ 27. Cyclidium spp. \\ 28. Epalxis exiguua \\ 29. Metopus es \\ 30. M. intercedens \\ 31. $M$. vestitus \\ 32. Parablepharisma pellitum
}

Aphanocapsa and Oscillatoria grow in the shallow areas, but can hardly act as primary producers. Instead, the sulphur bacteria whose biomass is much greater probably use soluble organic matter of unknown nature and become primary producers. We have recently found that ${ }^{14} \mathrm{C}$ is taken up from urea and glucose present in a medium containing living Thiothrix. The low dissolved oxygen in Warm Mineral Spring and its run is easily compensated for by the presence of oxidized sulphur and oxygen-containing organic compounds as long as there is biological action which is easily demonstrated.

This work was done under a grant-in-aid from the National Institutes of Health, U.S. Public Health Service.

\section{REFERENCES}

Bisset, K. A. \& Grace, B. (1954). The nature and relationships of autotrophic bacteria. In Autotrophic Micro-Organisms. Symp. Soc. gen. Microbiol. 4, 28.

Devidé, A. (1952). Zwei neue farblose Schwefelbakterien: Thiogloea ruttneri, n.gen., n.sp., und Thiogloea ragusina n.sp. Schreeiz. Z. Hydrol. 14, 446.

FaUst, L. \& WolfE, R. S. (1961). Enrichment and cultivation of Beggiatoa alba. J. Bact. $81,1$.

Ferguson, G. E., Lingham, C. W., Love, S. K. \& Vernon, R. P. (1947). Springs of Florida. Bull. Fla geol. Survey, no. 31. 


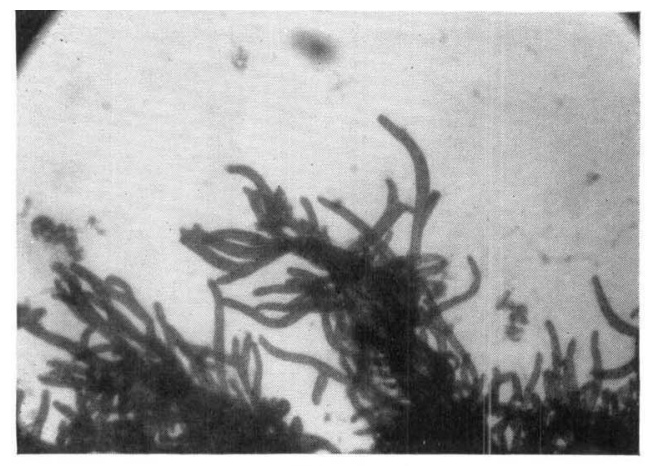

Fig. 1

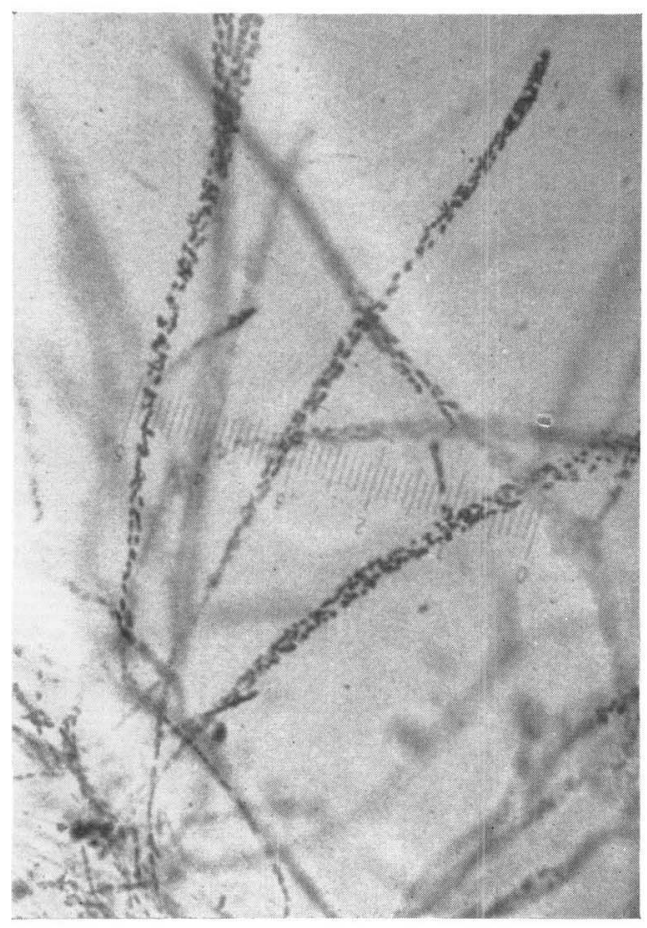

Fig. 3

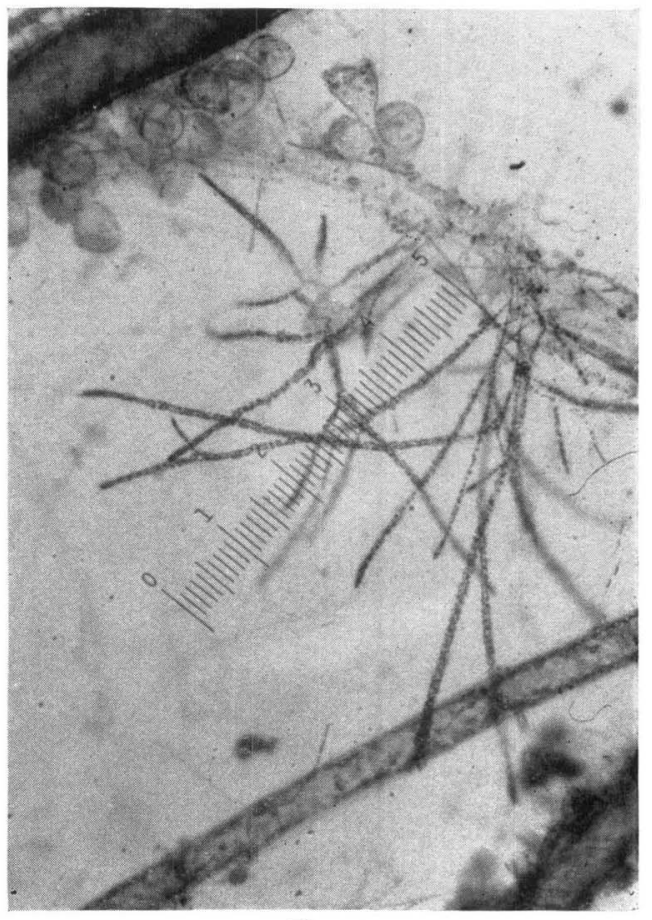

Fig. 2

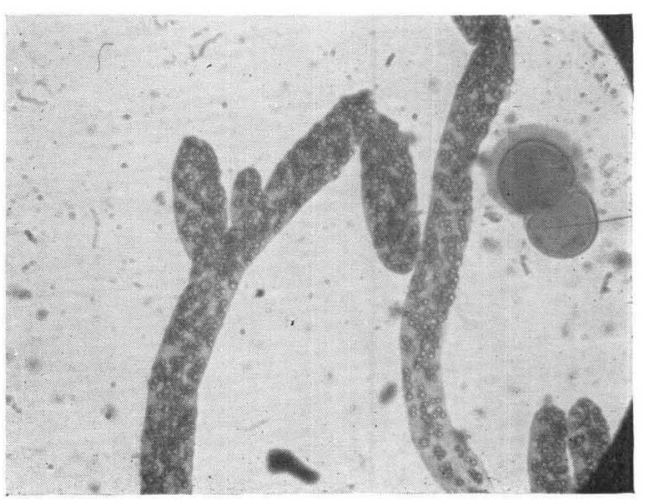

Fig. 4 

Hartman, O. (1959). A new nereid worm from Warm Mineral Spring, Fla., with a review of the genus NICON Kinberg. J. Wash. Acad. Sci. 48, 263.

Hollande, A. (1952). Classe des Chloromonadines. In Traite de Zoologie, Vol. I, p. 1. Ed. P. P. Grasse. Paris: Masson et Cie.

Ivanov, M. V. (1957). Participation of microorganisms in the formation of sulphur deposits in Shor-Su. Microbiology, Moscow, 26, 538.

Lamanna, C. \& Malette, M. F. (1953). Basic Bacteriology. Baltimore, Md., U.S.A.: Williams and Wilkins Co.

Odum, H. T. (1957). Trophic structure and productivity of Silver Springs, Florida. Ecol. Monogr. 27, 55.

Pringsheim, E. G. (1949). The relationship between bacteria and Myxophyceae. Bact. Rev. 13, 47.

Scotten, H. L. (1951). The isolation and study of pure cultures of Beggiatoa species. Master's Thesis, Indiana Univ., Bloomington, Indiana, U.S.A.

Skerman, V. B. D., Dementueva, G. \& Carey, B. J. (1957). Intracellular deposition of sulphur by Sphaerotilus natans. J. Bact. 73, 4 .

Stokes, A. C. (1886). Notes of new fresh water infusoria. Proc. Amer. phil. Soc. 23, 562.

Upноғ, J. C. T. (1927). Zur Okolgie der Schwefelbakterien in den Schwefelquellen Mittelfloridas. Arch. Hydrobiol. 18, 71 .

WAITZ, S. \& LACKEY, J. B. (1959). Morphological and biochemical studies on the organism Sphaerotilus natans. Quart. J. Fla Acad. Sci. 21, 4.

\section{EXPLANATION OF PLATE}

Fig. 1. Portion of a mature colony of Thiodendron mucosum to show branching. Colony stained while living with aqueous safranin. $\times 400$. Photographed with Kodak $682 \mathrm{C}, \frac{1}{20}$ sec., at f. 4.5. Fig. 2. Photograph of an old colony of Thiodendron mucosum attached to the stalk of a colonial vorticellid. $\times 400$. Photographed with Zeiss Contaflex IV using Dupont SX-Pan film, ASA-4000, $\frac{1}{2} \frac{1}{5}$ sec. at f. 2.8 .

Fig. 3. Portion of a mature colony of Thiodendron mucosum to show the distribution of sulphur in the colony fingers. Note the frequent linear aggregates, which indicate the long axes of unstained individual cells. The black pointer at the left ends on a Chroococcus turgidus colony (Blue green alga). $\times 750$. Photographed with Kodak $682 \mathrm{C}, \frac{-1}{20}$ sec., at 4.5.

Fig. 4. Photograph of a mature living colony of Thiodendron mucosum, to show its arboroid appearance. $\times 400$. Photographed with Speed Graphic, Century, $2 \frac{1}{4} \times 3 \frac{1}{4}$ using Ansco Super Hypan film, $\frac{1}{25}$ sec., at f. 4.5. 